\title{
First-year student aspirations: A multinodal analysis
}

\author{
Jane Grellier
}

School of Media, Culture and Creative Arts, Curtin University, Perth, Western Australia

\begin{abstract}
This article explores the aspirations of first-year university students in a particular socio-geographic context, by juxtaposing this context with those of Western universities in the 1970s. The rhizomatic analysis enables student voices and personal narratives to complement, extend and undercut the words of published researchers and of the university administration. As with other rhizomatic analyses, its non-linear structure, without evident beginning and ending, permits readers to begin at any point, making multiple connections between nodes. Readers create their own intertextual connections, and are encouraged to read the students' aspirations in the context of their own undergraduate experience.
\end{abstract}

Keywords: rhizomatic analysis; first-year students; student aspirations

Jane Grellier coordinates the First-Year Communications Program in the School of Media, Culture and Creative Arts at Curtin University, Perth, Western Australia. She is currently undertaking auto-ethnographic research of first-year students' experiences and responses to learning. Her research interests are reflective practice, qualitative research methodologies, and discipline-specific literacies.

Correspondence to Jane Grellier, School of Media, Culture and Creative Arts, Curtin University, GPO Box U1987, Perth, Western Australia 6845. Email:

j.grellier@curtin.edu.au 


\section{First-year student aspirations: A multinodal analysis}

\section{Rhizomatic analysis}

This rhizomatic analysis explores the aspirations of first-year students in a West Australian university at the end of the first decade of the $21^{\text {st }}$ century. The article contributes to the growing body of rhizo-/rhizomatic analysis, founded on the philosophies of Deleuze and Guattari (1987), who advocate the figuration of the rhizome for its power to "shake and uproot" $(1987,25)$ the Western binary, hierarchical figuration of the tree. Feminists and critical theorists in education, in particular, have embraced the rhizome in order to resist and challenge dominant institutions and structures, to give a voice to the silenced within these structures, and to make the invisible visible.

The rhizome grows through transversal connections; it is democratic and open, with every node connecting to every other node in an infinitely expandable system (Deleuze and Guattari 1987). It thus allows us as readers and writers to be in the middle of a text rather than working to begin or end it (Alvermann 2000; Hagood 2004; Lather 1997; Sellers and Gough 2010): the human "becomings" of Deleuze and Guattari (1987). By disrupting boundaries and previously held connections, the rhizome enables us to make new connections, which are multiple rather than linear (Grosz 1994; Kamberelis 2004), the "rhizomatics of proliferation, crossings, and overlaps" (Lather 1997, 299).

Many rhizomatic analyses intersperse theoretical references with the words of research participants, personal narrative and poetry, and the imagined voices of choruses, readers and even, in Lather's case, angels (Honan 2007; Lather 1997; O'Riley 2003). This multivocality breaks down the hierarchies that privilege the academic over the personal, the theories of researchers over the experiential voices of the "researched". 
The rhizome is one of a range of postmodern figurations that lead "toward a less comfortable social science" (Lather 1997, 285) - George Marcus's often quoted “messy texts" $(1994,286)$. While uncomfortable, these texts are richer, more satisfying and more "capable of helping us tell a better story" (Lather 1991, 15) than traditional texts. Elizabeth St Pierre advocates that we move into "the turbulence masked by the simulacrum called coherence ... working bewilderment for all it's worth" (St Pierre 1997, 281). She sees this bewilderment resulting from texts that urge us to live "at a higher degree, at a faster pace, in a multidirectional manner" (Braidotti 1994, quoted in $\underline{\text { St Pierre 1997, 281). }}$

I choose to work bewilderment in this paper by juxtaposing texts that challenge, complement and undercut each other, and inviting readers to create their own choruses from them. I combine voices from recognised academic authorities, from university administrations, from my students, and from various parts of myself in order to contest the accepted hierarchies of knowledge, and give voice to some of the most marginalised people within universities: first-year students. My analysis is placed within the burgeoning work on the First-Year Experience (FYE) in Western educational circles. In Australia, seminal research has been conducted over the past two decades (McInnis, James, and McNaught 1995; McInnis and Hartley 2000; Krause, Hartley, James, and McInnis 2005; James, Krause, and Jennings 2010), which seeks to create snapshots of the first-year cohorts in Australian universities. Issues considered include students' motivations for study; their study-work balance; their involvement in campus life; and the approaches to teaching and learning that are effective for these students. Many Australian universities now have dedicated FYE centres, usually involving research into first-year students, teaching and learning programs, and student support centres. 
In the United States, educators have been focusing on the first-year experience for nearly three decades, with national conferences and research centers now proliferating. For example, the $30^{\text {th }}$ Annual Conference on the First-Year Experience took place in Atlanta, Georgia in 2011. Other Western countries have also seen increasing focus on the FYE. In 2008, the Higher Education Academy in the United Kingdom published a national report on the first-year experience (Yorke and Longden 2008); and in the same year the first South African conference on the first-year experience took place.

Despite this rich and pervasive work, however, many individual first-year students in my research felt less empowered than their more senior counterparts:

No, most of our lecturers don't know our names this year. Maybe they're waiting to see if we survive first year. Then they'll think it's worth putting some effort into us. It's like sink or swim - if we swim then they'll take us seriously next year. (James White ${ }^{1}$, first-year student)

For the past ten years, I have coordinated the First-Year Communications Program at Curtin University, in Perth, Western Australia, which provides compulsory semester-length credit-bearing academic communications units (called "courses" or "programs" in other institutions; generally called "first-year seminars" in the US) to most first-year students of Humanities, and Science and Engineering. I often see our role as to walk alongside the students for the first semester of their course, but I have never before taken the chance to go with them into their discipline-based classes. For the past two years, I have undertaken an auto-ethnographic research project to create a snapshot of the first-year students in this university, exploring their views about what constitutes learning, and about the conditions that enable and hamper this learning. In

\footnotetext{
${ }^{1}$ All student names in this article are pseudonyms, but their details are accurate.
} 
the writing that arises from this project, I place their voices alongside the voices of their teachers and the senior administration in the institution. As part of this project, I have observed urban planning and medical imaging lectures, and ecology and engineering workshops, and interviewed fifteen volunteer students from these two Faculties. I recruited these latter students by sending invitations through other Communications lecturers, rather than conducting research with my own students, which would have raised issues of conflict of interest. Those who answered the invitation were atypical of the general student cohort - there was a larger proportion of mature-aged students (that is, students over 19 years old), a much smaller proportion of overseas students, and most were confident and even outspoken, prepared to contact a lecturer they did not know in order to volunteer their participation. In a later article I will analyse this volunteer group, and examine how the group composition might have shaped the voices I was hearing. The group consisted of 4 female students and 11 males, with only 4 of them having come to university directly from school. Two of the 15 came from homes in which English was not the first language, but both were extremely fluent and confident in English. A sixteenth student volunteered to be interviewed, gave me a piece of reflexive writing about his first year at university (not a required part of the process), but then left university before I could interview him, and did not leave a contact address. Despite the fact that I was not able to interview him, I have chosen to include his written voice in my research because it is one of the often- silenced voices of those who leave university before completing their studies.

Their different voices now resonate with my own voices as teacher, academic, reflective practitioner, colleague and student (current postgraduate student; undergraduate student in the early 1970s), with the voices of published researchers in many fields (tertiary education, academic literacy, critical theory, feminism, postmodern 
research, and so on), and with the diverse voices of the institution in which I work. My choice of the rhizome enables me to interleave my students' and colleagues' voices with the voices of the institution and of academic researchers, in a transversal construction that by its nature can never be finite: it is hesitant, partial and ambiguous (Clifford 1986; Crang 2005; Denzin 1997; Lather 1991), but as such aims to construct a rich map that values the voices of the students and myself alongside those of academia and the institution.

My decision to interleave the voices of current students with my own narratives of undergraduate study in the 1970 s and of academic work in the early 21 st century has also been shaped by the work of the many feminist auto-ethnographers who struggle with the challenges of integrating personal narrative and theory (e.g. Kondo 1990; Mankekar 1999; Narayan 1993). I support Dorinne Kondo’s (1990, 303) advocacy of "[m]aking a space in academic discourse for the personal and experiential".

\section{Node: Graphic image of rhizome}

This drawing of the rhizome of cimicifuga racemosa or Black Cohosh was created in the $19^{\text {th }}$ century by brothers J.U and C.G Lloyd, and richly represents the complex, open and infinitely expandable rhizomatic system suggested by Deleuze and Guattari. 


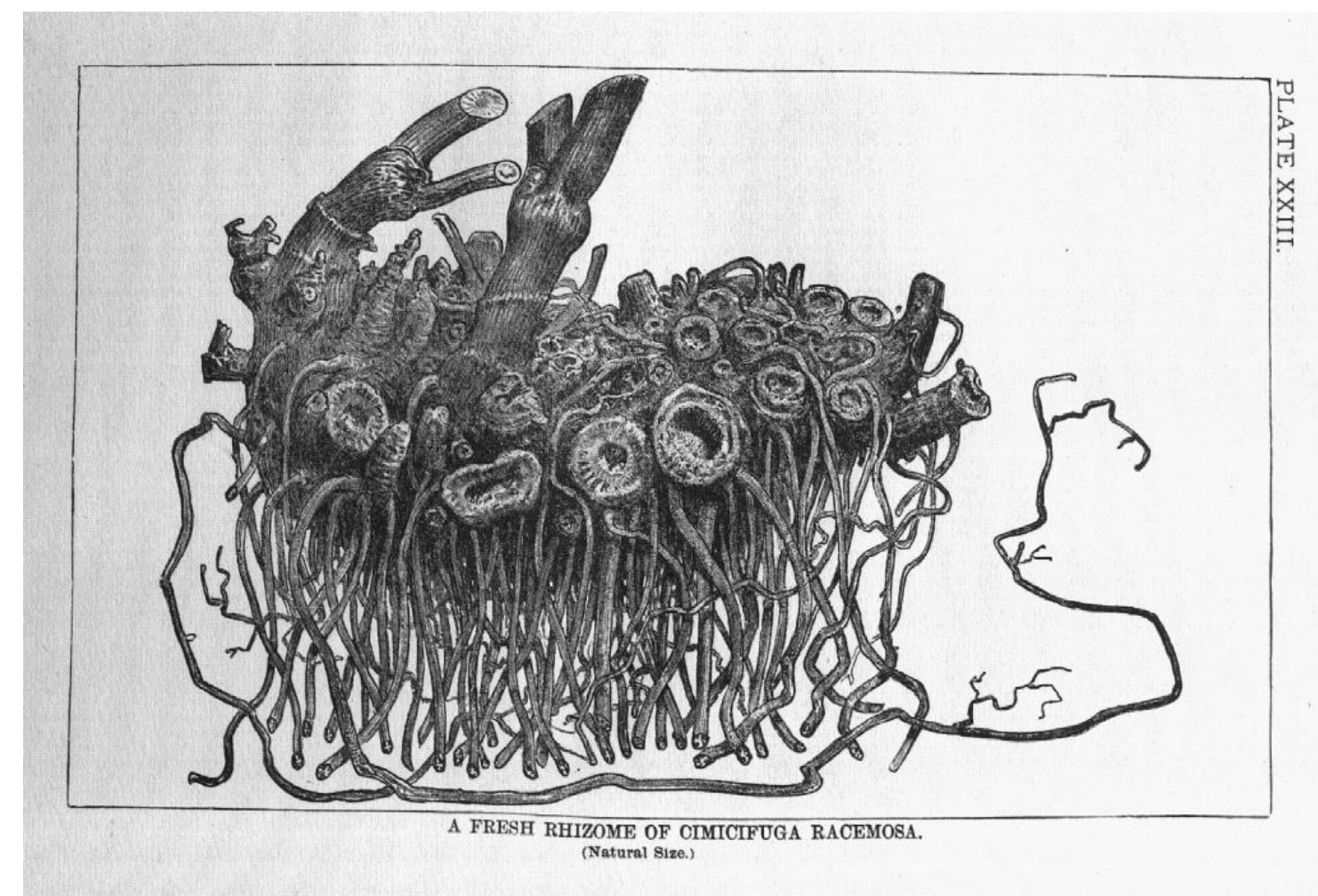

Figure 1: Rhizome of cimicifuga racemosa (Lloyd and Lloyd 1884-85, Plate 23)

\section{Node: Henry Giroux on his Education students}

Most of our students are very comfortable with defining themselves as technicians and clerks. For them to be all of a sudden exposed to a line of critical thinking that both calls their own experience into question and at the same time raises fundamental questions about what teaching should be and what social purposes it might serve is very hard for them. They don't have a frame of reference or a vocabulary with which to articulate the centrality of what they do. They are caught up in market logic and bureaucratic jargon. (Giroux 1992, 16)

Henry Giroux made this comment in a published conversation with unnamed colleagues at Miami University in Oxford, Ohio, where he had been a professor of education for most of the 1980s. In this position he was seen by many as "a leading spokesperson for radical education in America today" (Giroux 1992, 10). 
Node: My own student voice, early 1970s

Like Henry Giroux, I was an undergraduate student in the late 1960s and early 1970s, when students and others in Western countries engaged in sometimes violent civil rights protests against a range of social ills, including the Vietnam War, capitalism in general, and the many inequalities and injustices they perceived had developed in Western societies. It was an era of full employment in Western Australia for tertiary graduates: if we thought at all about future careers, we were confident that professional positions would be available to us when we were ready to work.

I went directly from high school to undergraduate studies in French Studies and English at the University of Western Australia. Like most of my fellow students I had a scholarship that paid my fees and gave me a living allowance, and I worked only during the summer holidays to make money to buy clothes for the following year. For the first two years of my study I was living at home with my parents 30 minutes' drive from campus, then I moved into an apartment close to campus for the final years. Unlike students in the US and UK, most Australian students at that time studied in their home State and where possible lived in private accommodation rather than university colleges (halls of residence) - the colleges were filled with students from rural areas of WA and from overseas. In most weeks I spent 40 to 50 hours on campus; when I wasn't in lectures, tutorials or language labs, I was in the library or the university coffee shop.

\section{Node: Institutional voice: Curtin University Office of Strategy and Planning}

It is impossible to find a physical location for this node - I reach it only through an online enquiry form, through which I apply for statistics on the current first-year students. An email reply arrives. 
Please find attached the statistics you require regarding the 2009 student cohort.

The pivot tables allow you to access information by age, gender, course and mode of entry. You are at liberty to use this information for your research provided that you do not misrepresent it:

- Total number of first-year students, 2009: 10095

- Number aged 16-18: 2180 (22\%)

- $\quad$ Number aged 19+: 7915 (78\%)

- Number aged 22-27: 2489 (25\%)

- Number offemale students: 5593 (55\%)

- Number of male students: $4502(45 \%)$

- Number of domestic students: 5257 (52\%)

- Number of international students, onshore and offshore: 4838 (48\%)

\section{Node: Student aspirational voices}

Of the fifteen students who volunteered to beI interviewed in the first phase of my research project, only three-four had come directly from school; ten-nine of the twelve eleven "mature-aged students" were between 22 and 27 years old.

This is probably the most serious I've been about anything for a while, exgirlfriends included. (Rob Jackson, aged 25, was returning to study after previous technical college and incomplete university study, travel and labouring work.)

I could easily just go and work up North for four months and make 15 or 20 grand and then go away for another year. I'd love the idea of doing that-I love travelling. But this is a crucial year for me for the fact that I have to pull my finger out, so to speak, and get into it-study. just being here is a huge start for 
me. At the end of the day if I failed first year I'd be upset because I like the guys that I'm studying with a lot, but I'd still be content with the fact that I'd given it a go and I'd definitely come back and do it again. ... It's a lot about proving to your mates that you can do it. ... I've already gone travelling around the world twice and I've seen all this and I've done all that, and now, I'm doing a course I'm really into. It IS a good feeling. The way that I've done it for me feels like it's worked out well. (Sam Tucker, aged 22, did not matriculate from high school and was embarking on his first tertiary studies.)

When I learn I feel that I grow into more of what I want to be. When I look at my life I want to see that I've achieved all that I can achieve, be the best person I can be, and at the moment I feel that learning is helping me get to that place. (Michael Foster, aged 22, did not matriculate from high school and had done previous incomplete technical college studies.)

\section{Node: Websites of the five universities in Western Australia}

The four public universities in WA publish their student numbers on their websites; no figures are published online for the private Notre Dame University. All universities operate on several campuses within the State, nationally and internationally.

- 2008 Curtin University undergraduate students: 30,000

- 2008 University of Western Australia undergraduate students: 15,000

- 2008 Edith Cowan University undergraduate students: 14,500

- 2008 Murdoch University undergraduate students: 13,000 
In the early 1970s, there was just one university in the State, the University of Western Australia, housed on one city campus, with total enrolments (undergraduate and postgraduate) of just over 10,000 (UWA 2009).

\section{Node: Researcher voices: diversity in the student population}

McInnis, James, and McNaught conducted a seminal study of first-year students in three Australian universities during the early 1990s:

'Diversity' is commonly taken to refer to age, gender, place of living, ethnicity, and socio-economic background. Such differences in the student population, however, are accompanied by a less visible diversity, one which finds its roots in family and educational backgrounds, values, attitudes and expectations. The expansion of participation has increased the critical mass for identifiable subgroups that were formerly significantly under-represented in universities. In this context, the notion of a mainstream of students is somewhat illusory. We believe that universities and academics are still to come to terms with the full implications of student diversity in higher education: the changing needs of the student population are not well-understood, especially with respect to motives, interests and academic abilities. (McInnis, James, and McNaught 1995, ix)

The diversity is further articulated in a recent study of 1300 WA university students:

Diverse student cohorts:

- $\quad$ first generation students

- mature age students

- international onshore students

- Aboriginal and Torres Strait Islanders

- $\quad$ students with parental/carer responsibilities 
- students from families of varied levels of parent education

- different study modes (full-time/part-time)

- varied disciplines. (Kinnear et al. 2008)

\section{Node: Student voices: the demands of work}

Many current students need to work a significant number of hours a week in order to support themselves and to pay fees, since undergraduate scholarships are now almost non-existent. Time demands are particularly complex for the mature-aged students. In addition to working in order to survive, some of these students support partners and children, and many run their own households.

I'm working 16 hours a week. I'm driving a forklift at the moment. I've got “Working in High-Risk Areas” tickets and qualifications, and I'm just trying to get the biggest hourly rate I can, and retail doesn't do that. (Rob Jackson) I work on the wharf and it's casual. You book your days off in advance so each week I book off two days for lectures. At the moment because it's a downturn I probably only work one shift a fortnight, but it chops and changes. When it's busy, it's really busy, and I could work seven 12-hour night shifts in a row. The money's great. (Sam Tucker)

On the other hand, several mature-aged students had saved money and moved back to live with their parents in order to devote more time to their studies.

It's been very significant, just the change of lifestyle for me, coming back from being out of home and working for a while, going back to being a student, living with Mum again. It's a big change, but it's a choice - it's not something I have to do. (Dave Robertson, aged 25, had previously done 6 months of a technical 
college course, and had then withdrawn from a university engineering course after a semester.)

\section{Node: Institutional voices: vocational courses}

A large proportion of Curtin's Humanities courses today are applied, vocationally oriented courses - Journalism, Film and Television, Librarianship, Creative Writing, Professional Writing, Urban and Regional Planning, Construction Management, Fashion, Textiles, Design Photography and 3D Design (which allows specialisation in jewellery, furniture or object design). In the 1960s and 1970s, none of these was seen as appropriate for university study; all were offered at Curtin's predecessor, the WA Institute of Technology, or at a technical college. The same is true of current Curtin Health Science courses such as Nursing, Speech Pathology, Pharmacy and Occupational Therapy.

Pages from the Curtin University website:

In December 1986 the Western Australian Institute of Technology (WAIT) was formally renamed Curtin University of Technology. ... the success of institutes such as WAIT ... would contribute to the eventual collapse of the binary system as they were expanding into areas traditionally associated with universities and the lines were becoming blurred.

We are widely recognised for the practical and applied nature of our courses, which equip graduates with essential skills through exposure to industry and business, and our research, which focuses on solving real world problems. This combination enables our graduates to be effective in the workplace immediately upon graduation. 


\section{Node: Student voices: choice of university}

Of the fifteen participants in the first phase of the project, ten were enrolled in vocational courses. Almost all of them valued the practical, applied nature of their course, and commented that it had been offered at Curtin or its predecessor WAIT for many years. Several compared their course favourably to the same course offered by the University of Western Australia (UWA), which they saw as being more theoretical, as well as much younger and therefore less well proven. Several had chosen Curtin, however, because the campus was closer to home or to their workplace.

I came to study at Curtin simply because no one's graduated from [his vocational course] at UWA yet. I could have easily gone to UWA, but I just didn't want to. No one knows yet what UWA's course is like - the course hasn't been accredited yet, and apparently the accreditation takes a long time. Curtin's been teaching it for 40 years ... the course started here, so it's just the experience thing. (Cadel Brown, aged 18, had come to university directly from school.)

[The following student could have gone to either Curtin or UWA, but he had just moved closer to Curtin] So I decided to apply for Curtin as my first choice, and I got accepted. Initially I would have liked to go to UWA, but starting at Curtin I think that I've made the right choice. I think it suits me, the campus suits me.... There are a lot of people that are a similar sort of age to me, that I can relate to on certain levels of music, talk about music or other interests. ... It's a comfort thing again, I suppose - now that I'm settled in here it seems like a place I'd like to study at.... From what I've heard of the UWA course it's not as focused and probably not as practical as this one. (Michael Foster) 
I still don't know which university's course is valued more by employers. The main reason I wouldn't go to the other universities is just the travel ... Curtin is much closer to home. (Chris Longley, aged 23, had done some technical college study, travelled and worked as a labourer; 2009 was his first year at university.)

\section{Node: My student voice: student life in the 1970s}

In the 1970s our units were each a full year in length, with assessment based completely on exams at the end of the year. We had to do assignments - mainly essays, with some language exercises in the French course - but these assignments were not credited towards our final marks. Lectures were large, particularly in first year, with up to 300 students, but tutorials were very small between 6 and 12 students. These tutorials were held in our tutors' book-lined offices, which looked onto a garden courtyard inhabited by loudly hooting peacocks. It was often difficult to appreciate the greenery through the office windows, however, since cigarette smoke from tutors and students filled the rooms during tutorials.

\section{Node: Researcher voices: student persistence}

In the survey conducted by Kinnear and others (2008), $80 \%$ of the 1300 West Australian students surveyed stated that goals and career aspirations were their main reasons for persisting in their course.

\section{Node: Institutional voices: Curtin University website}

We have close links with corporate business, industry, government and the community and our courses have a strong practical focus, with most involving vocational or work experience components. As a result, Curtin graduates are 
job-ready and prepared, with skills that enable them to make a genuine and positive influence in a continuously changing world.

\section{Node: My teacher voice: student life in the 21st century}

Campus life for $21^{\text {st }}$ century students is both healthier and more regimented than in my undergraduate days. While the air might be clearer, the tutors' offices have been replaced by bare classrooms, the painted brick walls dotted with occasional tattered posters and globs of blu-tak. The padded arm chairs circling the walls of my former tutors' offices are now metal student desks and chairs in rows or clusters. Students are more likely to be looking into the backs of those in front than facing into the centre of the room, thus increasing the "classroom" feel of the tutorial rooms. Tutorial sizes vary but they are generally between 20 and 30 .

Continuous assessment has helped students manage their time, and is certainly a fairer and more accurate measure of their achievement than a one-off examination; it has, however, created a sense of inexorable pressure, as students move from one assessment task to another without time to explore their ideas. While semester-length units have allowed students a greater variety of subjects than our year-long units did, and have divided the assessment into more manageable chunks, they have also increased the regimentation of deadlines, regular tasks, and marks.

\section{Node: My student voice: protest and rebellion}

In the evenings, tired of the too-silent library, I used to work in the Arts Common Room, a plain square room with white painted brick walls and low- 
slung wooden-armed chairs padded in red vinyl. The chairs were arranged in four parallel rows of about 8 chairs each - two rows facing each other against the side walls and two lined up back to back down the centre of the room. It was a mind-numbing physical environment, but the company compensated for that. People studied spasmodically, with lots of chat and movement, people going in and out constantly. The same students would come in regularly - all of us had long hair, both males and females, and all wore jeans; in winter many wore the second-hand army greatcoats popular at that time. One student would bring his guitar - I remember him singing only one song, Arlo Guthrie's “Alice's Restaurant", over and over again.

This was the time of Bob Dylan and the Beat poets, of Civil Rights marches and anti-Vietnam protests. Students and lecturers at the Sorbonne had rioted in the streets of Paris in 1968; US soldiers had fired on unarmed student protesters at Kent State University in 1970, killing and wounding more than a dozen, and leading to major student protests throughout the US; the Baader-Meinhof Gang in Germany and the Red Brigades in Italy conducted violent struggle against their governments. Conscription was in force in Australia-brothers and friends of many of us were in Vietnam at that time. I often sat next to one male student in the Common Room who had already been drafted, but whose conscription orders had been postponed provided that he passed each year at university. For him, study for exams was even more stressful than for the rest of us. Some of the regulars in the Arts Common Room called themselves "Yippies" (Youth International Party), a group founded in the late 1960s US by Jerry Rubin and Abbie Hoffman, dedicated to social activism and theatrical, often violent, public protests. While I was on the margins of this group, all of us in the 
room would be caught up in their conversations. In 1971 a bomb was planted at the offices of the Department of Labour and National Service in Perth, responsible for the conscription of young Australians to fight in the Vietnam War. The two convicted of the bombing had been regulars at the Arts Common Room. Other regulars are now, or have been, members of parliament, lawyers, school principals, senior university academics, and heads of government departments and private organisations.

\section{Node: Student voices of the 1960s}

The era of student activism was brief and dramatic throughout Western countries. Todd Gitlin, a member of the Students for a Democratic Society (SDS) organisation which was in the forefront of the movement in the US, presents it as an almost religious movement:

At their strongest, the movements of the Sixties amounted to an incomplete Reformation. As in sixteenth-century Germany, the urgent young, disgusted by the corruption of values, beat on the doors of established power in the name of reform. Rebuffed, they reconsidered not only their institutions but their identities, their nature, their mission. Their dissidence deepened. They developed rituals of self-transformation and unification. (Gitlin 1987, xxii)

\section{Node: Student voices: campus life in the 21st century}

The younger research participants reported studying on campus, but all the mature-aged ones chose to study at home when they were not in classes. None of the students had joined the student guild, and only one reported becoming involved in campus activities beyond her own department - a mature-aged student who had decided to spend more 
time on campus in order to devote herself to study and to volunteering in an international student organisation. She saw this an opportunity to enhance her future career prospects:

My thing about why I want to do this is for the opportunities, not social opportunities, but more the networking opportunities for a career and building up my resume. Because if you only go through uni and only have your degree, you don't have any experience and no extra things, you won't be looked at. I like to give back too, but this helps me. (Marie Phillips, aged 22, had done a technical college course in photography but it had not met her expectations; she had started university studies part-time and then changed to a full-time enrolment after a semester.)

Phillips' determination to increase her employability is a reminder that the economic conditions today's students face are very different from those my contemporaries faced on graduating.

\section{Node: Researcher voices: student engagement on campus}

By studying at home and working many hours of paid work each week, students lack the experience of campus life that was considered valuable in earlier decades, and that underpinned student activism, as well as involvement in university sporting, cultural and social communities. This detachment is exacerbated in Western Australia because most students live in private accommodation some distance away from campus. (Only one of the fifteen participants lived on campus - a mature-aged international student who chose not to involve himself with any student groups.) In an echo of Henry Giroux's complaint, McInnis, James and McNaught (1995) claim that lack of time on campus also reduces students' critical engagement with their discipline: 
In some courses, the presence of many [de facto part-time students] can reduce the shared view of university experience to a process of acquiring technical knowledge (even in the humanities) with a bare minimum of on-campus contact. (McInnis, James and McNaught 1995, 112)

\section{Node: Student aspirational voices}

The concept of seeking merely to acquire technical knowledge does not adequately depict the mature-aged participants in my research, however. While all had worked regularly since leaving school, they reported seeking positions that would be more satisfying and challenging, as well as trying to improve their employment chances in difficult economic times. They were committed to studying many hours at home in order to succeed:

So it wasn't until I was in Greece and looking at all this architecture that I said, “You know, I want to create things like this.” It amazed me, it was like a legacy. These guys have worked hard and they've left something behind. I don't want to be like a guy who just crunched numbers for 40 years. (Rob Jackson)

I don't want to have a mediocre life, and this is my way of securing my future.

(Dave Robertson)

For a lot of young people who have never experienced a recession or any sort of financial crisis, they just want to safeguard themselves with a professional qualification. ... Independence is something to be proud of. (Larry David, aged 22, was brought up in a rural town and had come to Perth to work as a musician, but done labouring work then begun tertiary studies when he realised he could not support himself in the music industry.) 
Several of them reported engaging critically with their lecturers while on campus, asking questions after lectures, sending emails or calling in to their offices. They valued lecturers who were passionate about their subject and responsive to their students.

One of the things that's most appealing is a lecturer actually explaining what makes them passionate about a subject. To know that, you begin to ask yourself as a student, "Wow, would that be something that would make me passionate about it as well?" And you think to yourself, "I'd like to look into it." I've found myself many times going home from a lecture and just going and visiting that particular thing. And you click onto it and read. And I'd come back to the next lecture looking for it again, and even ask questions about it. (Gabriel Morelli, aged 27, had migrated to Australia and learned English in his teens; had not matriculated from high school, and had done some technical college studies before embarking on university study.)

\section{Node: Researcher voices: the seventies}

The student civil rights movement was fading by the early 1970s. Gitlin (1987) dates the end as early as 1970, though his disillusionment with the violent directions the movement took under the influence of Jerry Rubin and others might explain this opinion. Others place the end in the mid 1970s. Roberta Lexier $(2004,84)$, for example, examines the early years of the Regina Campus of University of Sasketchewan, in the 1960s and early 1970s:

The reasons [for the decline of student activism on Regina Campus] relate to the larger decline of the student movements throughout North America by the mid1970s. Just as there were complex reasons for the initiation of political activism, 
there were numerous factors accounting for its decline. Many of the activist students had graduated from university and were focused on the responsibilities of employment and family. The new generation of students had little knowledge of institutional history or interest in politics. The liberal arts program began to decline on the Regina Campus as professional programs in Administration and Engineering expanded and shifted the focus away from critical thought to job training. Students also felt they had largely failed in their demands and became less optimistic about the possibilities for change. As well, the affluence and prosperity of the 1960s, which had made concerns about job possibilities irrelevant, was replaced by economic decline and inflation. Students became less concerned with politics and more focused on their future opportunities in the job market. (Lexier 2004, 97)

\section{Node: My student voice: the maverick student}

In the early seventies many Arts students at UWA had the sense that intelligent mavericks could subvert the system and be valued for it, that our lecturers appreciated and rewarded students who were critical thinkers. At the end of my first year of English studies, a rumour circulated that one of the students who was renowned as radical and highly intelligent had refused to answer the questions set on the annual exam paper. The rumour held that he had written criticisms of the questions on the paper, created his own question and answered it, and had been awarded an A grade. Whether this was true is unimportant; what was important is that most students believed it, admired the student, and felt he deserved the A grade. Some of our lecturers were modelling rebellious attitudes, and we had heard that many of the students who had rioted in the 
streets of Paris in 1968 had been accompanied (and sometimes led) by their lecturers.

\section{Node: Institutional voices: accountability}

The accountability emphasis of the early $21^{\text {st }}$ century leaves no room for the maverick student. Learning outcomes are documented publically for all courses at Curtin, outcomes of individual units are mapped to the course learning outcomes, and assessment criteria for all assignments are mapped to those. The university requires that all course developments be accompanied by an "accountability statement", countersigned by the Head of School, Pro Vice Chancellor and Vice Chancellor:

I confirm that the course development $X$ adheres to the University documentation and process requirements as stipulated in the University Academic Policies and Procedures manual and that the role of the Faculty/School as stated in the document "Delegation by Council of Course Approvals”, adopted by Council resolution C197/96 (see Appendix 1), has been observed. ("Accountability statement for centrally approved changes" document available on the university website)

Even the Student Guild prefaces its annual report with a statement of accountability:

This ensures the accountability of all the office bearers of the Guild to the students that they represent. (Curtin Student Guild, 2005-2009).

Most academics structure their units by teaching to the assessment tasks, and conduct comparability meetings to ensure as far as possible that the marking is equitable. In 2009 the Curtin Office of Teaching and Learning awarded grants totalling 
more than $\$ 300,000$ to projects seeking to improve the moderation of students' assignments (Curtin University Office of Teaching and Learning, 2009).

\section{Node: Researcher voices: students from diverse backgrounds}

Consistent and thorough documentation supports the learning of the great majority of students by helping them to understand how each unit fits within their course, and how they can complete and succeed in each assignment. This is particularly important because of the increase in the number of students from diverse backgrounds who have not internalised middle-class professional expectations in their home life and schooling (Lea and Street 1998; Lillis and Turner 2001).

\section{Node: Student voices: acceptance of bureaucracy}

Students keep a tally of the marks they have gained as the semester progresses, and most limit themselves to activities that attract marks. They expect assessment to be consistent, and the majority accept (and indeed welcome) the authority of the university. This system has also created a clear distinction between those students who are aiming for high marks throughout their course and those who are satisfied with bare passes, because it gives students an early idea of their progress in many units, and allows them to adjust their efforts to suit their goals.

After the first semester things have almost become "same old". It's a good thing. My learning has been helped by knowing the course structure, with unit outlines online, so you know what's coming. There's no real surprises. (Cadel Brown, who consistently gained High Distinction grades in his first year of studies)

The creative individualist may, however, find such regimentation stultifying. 


\section{Node: Faculty voices: technical and clerical demands}

It is not only the students who are affected by the "market logic and bureaucratic jargon" criticised by Giroux - the entire university system is structured on this basis. Academics at Curtin University are being caught up, with much complaint, in the increased technical and clerical demands of bureaucratic university systems:

The new documentation system we are required to use is a very significant change from the one we have used previously. A lot of the sections are inappropriate for anything but run-of-the-mill teaching. I find it all dismaying. [Colleague]

Until ten years ago, some of my colleagues had secretaries type out their unit outlines and student handouts. Now all academics have to be able to use complex templates to produce documents that follow guidelines designed to protect the university against criticism, complaints and legal cases. They are also required to prepare their own audiovisual aids for formal presentations and posters; upload student materials onto electronic portals; compile class lists and submit exam results electronically; and follow stringent technical processes to submit documents for publication. This bureaucratic load has filled up the hours they might have devoted in the past to professional research, or to building their collegial communities and networks. Participant student Peter Primrose, whose father is an academic, had noticed changes in his father's work patterns over the past decade:

They're too stressed out and there's too much bureaucracy for them to have time to be friends with each other. (Peter Primrose, aged 18, had come to university directly from school.) 


\section{Node : Researcher uppity voices}

Many radical educators (e.g. Lather 1991; Tompkins 1996; Williams 1991) have suggested that students tend to resist critical pedagogies and concepts, and to support the institutional and societal status quo. While the sixties and early seventies saw a temporary rise in student activism, this was an exceptional period. Nevertheless, some radical voices still challenge oppressive hierarchies in the university and in society at large. Michelle Fine $(1994,78)$ describes these people as speaking with the "uppity voices of informants and researchers who speak against structures, representations, and practices of domination." For example, Henry Giroux, one of the most vocal uppity voices speaking today, reflects in a personal essay on the power of traditional racial and class stereotypes:

Rarely did I encounter a vocabulary [among family, friends, school, and the larger popular culture] that ruptured or challenged the material relations of racism or the stereotypes and prejudices that reinforced race and class divisions. It was only later, as I entered the sixties, that I discovered in the midst of the civil rights and antiwar movement languages of dissent and possibility that helped me to rethink my own memories of youth, racism, and class discrimination. (Giroux 1997, 12)

\section{Node: Student uppity voices}

Two of the fifteen student participants also spoke in uppity voices, challenging the rigidity of both students and teachers. One of them reflected on a major group assignment he had just completed in his first semester of study in which the students had been invited to be as creative as they could: 
Ijust felt my group was a bit [pause] constrained, I'm not sure why. There was a leadership struggle between one of the other guys in the group and me, and his option was a lot safer. I wasn't worried by the marks so much, I just wanted to take a risk because it would have been more enjoyable, and I believe it would have paid off, I was pretty sure it would have paid off better. ... [Question: If you'd been told you could take a risk but it might not be worth so many marks, what would you have done?] ... I still think I would have attempted it because all the other groups were conforming to mediocrity and they were all pretty much mirrors of each other, and I just felt, I don't know, I'd rather make a wave than just bob around. (Ben Wright, aged 19, had travelled and worked since leaving high school.)

Peter Primrose, the second uppity voice, discussed how he felt different from most other students he had met: while they had come to university to get a job, he “cared more about what I'm learning than about getting a job”. While Wright criticised his fellow students for not taking risks, Primrose also challenged some of his teachers in a written reflection on his first-year studies:

I'm angry with [lecturers in a particular subject] because they make a subject I'm interested in a bore. They're poking the stick in the wrong hole. I overall think that the university or (more accurately) the people who comprise it are reasonably compassionate and understanding when it comes to enabling my learning. That is not to say, however, that I don't feel like a tortured student hanging from a web of bureaucracy. The problem is, whilst I have an endless bag of ideas for how to improve teaching, learning and examination, most are impractical. For example, I am quite adamant that assessment at university (in subjects like maths and the physical sciences) does not in any way test the right 
kinds of understandings. It's all very good and well to be able to plug numbers into equations and memorise which equations apply where, but this does not display the understanding of physical principles that good scientists require. (Peter Primrose)

Both of these students have parents involved in education. Their familiarity with educational systems perhaps gives them a safety net from which they feel they can take risks without endangering their future careers. On the other hand, several of the other participants also have teacher or academic parents but focused in their first year on fulfilling the university requirements in order to graduate successfully. Wright saw his undergraduate years as an opportunity for him to explore a range of paths before having to "go in one direction" after graduation:

I think eventually I'm going to have to come out of limbo and unfortunately [emphasised] go in one direction, and I think that's just the reality of life. I don't enjoy the idea that you go to school, then you go to high school, then ... I don't like that it's placed out like that. I don't think that as soon as I've finished my degree I'll get a well-paid job, then I'll get the house and the kids and the dog.[long pause] I've got all these wild ideas but in the end reality will determine what happens. ... [Question: We keep getting back to rigidity. Is reality going to be rigid?] Economic reality will be rigid. Unless I was completely to throw away materialism and the kind of life I live, unless I was to become a complete left-wing bushman that lived as a hermit on a mountain ... If I want to continue on the path that I want, I'll have to take into account and duck and weave through the economic realities. (Ben Wright)

Primrose used the same image of travelling in a particular direction, but held out some hope that reality would not constrain him as much as Wright feared: 
I hope this is the truth - that I'll be able to move in all different directions in my life. (Peter Primrose)

He spoke the first phrase hesitantly, however, suggesting his concerns about constraints to come.

A sixteenth student, Alan Grove, also spoke with a strong uppity voice in a written reflection on his first semester of study.

To put it bluntly, I have discovered that I find maths and science to be incredibly uninteresting as a university subject, with all the wonder and excitement totally drained out of it and now I think that four years of equations and numbers sounds more like hell. While I surely have been unsuccessful in learning the course I chose, I have learnt more about myself, mainly what I am willing to do and what I'm not. Not entirely sure it was worth the tuition fee but that's life and it's my own fault for not addressing the problem earlier. Usually the most difficult lessons to learn are the ones about yourself. The experience has not discouraged me from university but rather taught me that I should apply to a course more involved in things like writing, discussion and deconstruction.

(Alan Grove, aged 19, had worked for one year after leaving school.)

Unlike Wright and Primrose, Grove came from a rural working-class background, and had no family support for university study. We had several informal conversations about university courses that might provide him with more opportunities to think critically than the one he was enrolled in, and about professions in which his uppity voice might speak. He did not complete most of his first-semester units, however, and disappeared abruptly from campus at the end of the semester, leaving ne contact details with the university system. 


\section{Node: Uppity voice of Henry Giroux}

Giroux (1996) tells similar stories of his early studies and professional life. He too came from a working class background, and made several attempts to complete undergraduate and postgraduate degrees; he was then refused tenure at Boston University despite a strong publication history in the area of radical educational theory, and unanimous support from tenure committees and prestigious academics. He concludes that both his socio-economic background and his political position were responsible for this rejection:

Working-class intellectuals do not fare well in the culture of higher education, especially when they are on the left. I have been asked many times since this incident whether I would have continued the critical writing that has marked my career if I had known that I was going to be fired because of the ideological orientation of my work. Needless to say, for me, it is better to live standing up than on one's knees. (Giroux 1996, 8)

Wright's desire to make a wave rather than just bob around resonates with Giroux here, as does Primrose's sense of wanting to ask challenging questions by poking the stick in the right hole. Perhaps Grove will return to university study in the future. He was certainly one student not seeking to be a technician or a clerk.

\section{Node: Researcher voices: the sixties}

Professor Simon Marginson of the University of Melbourne reflects on the very particular era of the sixties:

We won't see a re-run of the late sixties and early seventies when affluence and full employment spawned a whole youth generation who were edgy, who directly confronted the dominant mainstream with demands for change. There are still 
individuals like that, but they no longer constitute a whole student culture.

(Anns 2005)

\section{Node: Pages from my reflective journal}

20 July 2009: ... As I interview more students I'm struck by how committed they are to their studies. Dave was the fourth this week to stress the significance of this year for him-it's like they're "girding their loins" for a huge effort to put their lives on new paths. And most of them comment on seeing 30 as the deadline for gaining professional qualifications - makes me feel very old! Last week Michael, who isn't yet in a permanent relationship, even talked about needing financial security so he could settle down and start a family by the age of 30. But I must keep in mind that the group who have volunteered to participate in my research are not representative of the student body. I've asked them all why they volunteered. Would like to write an article about this next year - would make an interesting study in self selection ...

3 August 2009: Starting to prepare for the November conference, and have just discovered a magnificent $19^{\text {th }}$ century drawing of a rhizome. I'll take it to the auto-ethnographic writing group next week - Liz and Jenny [two members who introduced me to Deleuze and Guattari] will love it! It's a great depiction of Michelle Fine's (1994, 72) “knottily entangled” relationships. I'm fascinated by the rhizome figure. Everywhere I look at the moment I see it - the "and ... and ... and ..." of infinite connection. ...

14 August 2009: ... Sam talked more about proving to his friends that he can succeed at university than about his own desire for success. Because he didn't matriculate, he feels that they consider him less intelligent than them (and I had 
the impression he was wondering about that himself - he's the only one so far to have mentioned the possibility of failing the semester). Most of the others have celebrated the fact that they alone have made the decision to return to studies. Larry even distinguished himself yesterday from some of the recent school leavers - they've been pressured by parents to study, while he made his own choice. I wonder if Sam's response will change in future semesters if he passes this one successfully - I hope he'll be prepared to come back and talk about it. Yet another reminder (if I needed one) about the pre-eminent place of selfconfidence in students' language development!

12 October 2009: This disembodied historical/academic voice isn't working. There has to be a different way of exploring the sixties contexts. I've found Gitlin's book useful and have just discovered an article by Lexier who discusses the sixties contexts in a Canadian university. But at the moment the sixties bits of my article are very clunky. I'm going to experiment with a personal voice, representing my own memories of being an undergraduate in the early seventies. After all, I was there, and I can set up some useful interconnections between my experiences and what I see happening now in my own university. So many feminist social scientists have paved the way for the blending of the personal and the academic - it's not as if I have to break new ground. ...

20 November 2009: ... Thinking about restructuring my article draft as a rhizomatic analysis. Could create a pun with "multinodal". Many advantages of this, not the least that it would allow me to split the bland academic voice into strands. The statistical background could become a series of institutional voices, and I could quote some of my colleagues (unnamed, of course) to portray their distaste for creeping bureaucratic demands. I could then reserve my academic 
voice for interpretive or explanatory comments at the beginning of each node (where necessary - many nodes would speak for themselves). ...

22 November 2009: ... Am pleased with the way the rhizome is working. As I move each node into different positions, I'm highlighting various connections and disjunctions - the voices complement, elaborate or buffet against each other. Great that I remembered the comment from Peter P about his dad being weighed down by bureaucracy in his academic position - nice complement to my colleagues' voices and buffet against the institutional ones. I've moved it into three different places already and am still not sure it's in the best one. Maybe there isn't a "best". It's a never-ending process, reminds me again and again about that bit from $D \& G$ - "detachable, connectable, reversible, modifiable, [with] multiple entryways and exits and [their] own lines of flight". It also fits well with the concept of ethnography as richly human though incomplete that I'm reading in so much of the current literature.

2 December 2009: Showed my rhizome to Ann [a poet friend] this afternoon over a long lunch. She felt it worked very well and she zeroed in on some nodal interconnections I hadn't noticed. I like the way the rhizomatic structure invites readers to make their own intertextual meanings - much more than traditional academic forms! They're creating their own maps, as $D \& G$ advocate.

\section{References}

Alvermann, Donna E. 2000. Researching libraries, literacies and lives: A rhizoanalysis. In Working the ruins: Feminist poststructural theory and methods in education, ed. Elizabeth. A. St Pierre and Wanda S. Pillow, 114-129. New York: Routledge. 
Anns, Robyn. 2005. Those were the days. http://monash.edu.au/pubs/monmag/issue162005/around-monash/around-activism.html.

Clifford, James. 1986. Introduction: Partial truths. In Writing culture: The poetics and politics of ethnography, ed. James Clifford and George E. Marcus, 1-26. Berkeley, Calif.: University of California Press.

Clifford, James, and George E. Marcus. 1986. Writing culture: The poetics and politics of ethnography. Berkeley: University of California Press.

Crang, Mike. 2005. Qualitative methods: There is nothing outside the text? Progress in Human Geography 29 (2):225-233.

Curtin Student Guild. 2005-2009. Annual report. http://guild.curtin.edu.au/go/publications/annual-report.

Curtin University Office of Teaching and Learning. 2009. Funding arrangements 2009. http://otl.curtin.edu.au/assessment/moderation/funding.cfm.

Deleuze, Gilles, and Félix Guattari. 1987. A thousand plateaus: Capitalism and schizophrenia. Minneapolis: University of Minnesota.

Denzin, Norman K. 1997. Interpretive ethnography: Ethnographic practices for the 21 st century. Thousand Oaks, Calif.: Sage.

Fine, Michelle. 1994. Working the hyphens: Reinventing self and other in qualitative research. In Handbook of qualitative research, ed. Norman K. Denzin and Yvonna S. Lincoln, 70-82. Thousand Oaks, Calif.: Sage.

Gitlin, Todd. 1987. The sixties: Years of hope, days of rage. New York; Toronto: Bantam Books.

Giroux, Henry A. 1988. Teachers as intellectuals: Toward a critical pedagogy of learning. Granby, Mass.: Bergin and Garvey. 
Giroux, Henry A. 1992. Border crossings: Cultural workers and the politics of education. New York: Routledge.

Giroux, Henry A. 1996. Fugitive cultures: Race, violence, and youth. New York: Routledge.

Giroux, Henry A. 1997. Channel surfing: Race talk and the destruction of today's youth. Basingstoke: Macmillan.

Grosz, Elizabeth. 1994. A thousand tiny sexes: Feminism and rhizomatics. In Gilles Deleuze and the Theater of Philosophy, ed. Constantin V. Boundas and Dorothea Olkowski, 187-210. New York: Routledge.

Hagood, Margaret Carmody. 2004. A rhizomatic cartography of adolescents, popular culture and constructions of self. In Spatializing literacy research and practice, ed. Kevin M. Leander and Margaret Sheehy, 143-160. New York: Peter Lang.

Honan, Eileen. 1997. Writing a Rhizome: An (Im)Plausible Methodology. International Journal of Qualitative Studies in Education 20 (5):531-46.

James, Richard, Kerri-Lee Krause, and Claire Jennings. 2010. The first year experience in Australian universities: Findings from 1994 to 2009. Melbourne: Centre for the Study of Higher Education, University of Melbourne.

Kamberelis, George. 2004. The rhizome and the pack: Liminal literacy formations with political teeth. In Spatializing literacy research and practice, ed. Kevin M. Leander and Margaret Sheehy, 161-197. New York: Peter Lang.

Kinnear, Adrianne, Mary Boyce, Sharon Middleton, and Heather Sparrow. 2008. Perceptions of successful students: Lessons for the first year experience. 11th Pacific Rim First Year in Higher Education Conference, 30 July. Hobart, Tasmania. www.fyhe.qut.edu.au/past_papers/papers08/presentation\%20files/7A.pdf. 
Kondo, Dorinne K. 1990. Crafting selves: Power, gender, and discourses of identity in a Japanese workplace. Chicago: University of Chicago Press.

Krause, Kerri-Lee, Robyn Hartley, Richard James, and Craig McInnis. 2005. The firstyear experience in Australian universities: Findings from a decade of national studies. Canberra: Department of Education, Science and Training.

Lather, Patricia Ann. 1991. Feminist research in education: Within/against. Geelong, Australia: Deakin University.

Lather, Patti. 1997. Drawing the line at angels: Working the ruins of feminist ethnography. International Journal of Qualitative Studies in Education 10 (3):285-304.

Lea, Mary R., and Brian V. Street. 1998. Student writing in higher education: An academic literacies approach. Studies in Higher Education 23 (2):157-172.

Lexier, Roberta. 2004. Dreaming of a better world: Student rebellion in 1960s Regina. Past Imperfect 10:79-98.

Lillis, Theresa, and Joan Turner. 2001. Student writing in higher education: Contemporary confusion, traditional concerns. Teaching in Higher Education 6 (1):57-68.

Lloyd, J.U. and C.G. Lloyd. 1884-85. Drugs and medicines of North America: A publication devoted to the historical and scientific discussion of the botany, pharmacy, chemistry and therapeutics of the medicinal plants of North America, their constituents, products and sophistications. Vol. 1. Cincinnati, Ohio: J.U. and C.G. Lloyd.

Mankekar, Purnima. 1999. Screening culture, viewing politics: An ethnography of television, womanhood, and nation postcolonial India. Durham, N.C.: Duke University Press. 
Marcus, George E. 1994. What comes (just) after "post"?": The case of ethnography. In Handbook of qualitative research, ed. Norman K. Denzin and Yvonna S. Lincoln, 563-574. Thousand Oaks: Sage Publications.

McInnis, Craig, Richard James, and Carmel McNaught. 1995. First year on campus: Diversity in the initial experiences of Australian undergraduates. Canberra: Australian Government Publishing Service.

McInnis, Craig, and Robyn Hartley. 2000. Trends in the first year experience in Australian universities. Canberra: Department of Education, Training and Youth Affairs.

Narayan, Kirin. 1993. How native is a "native" anthropologist? American Anthropologist 95 (3):671-86.

O'Riley, Patricia A. 2003. Technology, culture, and socioeconomics. New York: Peter Lang.

Sellers, Warren, and Noel Gough. 2010. Sharing outside thinking: Thinking (differently) with Deleuze in educational philosophy and curriculum inquiry. International Journal of Qualitative Studies in Education 23 (5):589-614.

St Pierre, Elizabeth A. 1997. An introduction to figurations: A postcultural practice of inquiry. Qualitative Studies in Education 10 (3):279-284.

Tompkins, Jane P. 1996. A life in school: What the teacher learned. Reading, Mass.: Addison-Wesley.

University of Western Australia (UWA). 2009. The University of Western Australia: History of the university. http://www.uwa.edu.au/university/history.

Williams, Patricia J. 1991. The alchemy of race and rights. Cambridge, Mass.: Harvard University Press. 
Yorke, Mantz, and Longden, Bernard 2008. The first-year experience of higher education in the UK: Final report. York: The Higher Education Academy. 